\title{
SMEAR LAYER REDUCTION IN ROOT CANALS PREPARED WITH TRIANGULAR AND RECTANGULAR FILES AS EVALUATED BY SCANNING ELECTRON MICROSCOPY
}

\author{
MEITA HERISA ${ }^{1}$, NONI MAHARANI ${ }^{1}$, RATNA MEIDYAWATI ${ }^{2}$, DEWA AYU NYOMAN PUTRI ARTININGSIH ${ }^{2 *}$, \\ KAMIZAR NAZAR ${ }^{2}$
}

${ }^{1}$ Conservative Dentistry Residency Program, Faculty of Dentistry, Universitas Indonesia, Indonesia. ${ }^{2}$ Department of Conservative Dentistry, Faculty of Dentistry, Universitas Indonesia, Indonesia. Email: dewaayunpa@yahoo.co.id

Received: 29 July 2019, Revised and Accepted: 21 February 2020

ABSTRACT

Objective: Root canal preparation procedures can produce a smear layer when in contact with the root canal wall, which can result in treatment failure. As such, the cross-section shape of the file may influence the production of smear layer. In this study, we compared the smear layer production at the apical third of the root canal wall between files with a triangular or rectangular cross-section shape.

Methods: Thirty-two human premolar samples taken from mandibles were divided into two groups whose root canals were prepared using files with either a triangular (One Curve ${ }^{\circledR}, \mathrm{n}=16$ ) or rectangular (Hyflex EDM ${ }^{\circledR}, \mathrm{n}=16$ ) cross-section shape. After preparation, the root canals were irrigated with a combination of $2.5 \% \mathrm{NaOCl}$ and $17 \%$ ethylenediaminetetraacetic acid (EDTA). The smear layers in the apical third of the root canal walls were observed using a scanning electron microscope and quantified according to the Foschi scoring system.

Results: The Mann-Whitney U-test revealed a significant difference between root canal preparations using the different file shapes. The group prepared with the triangular file produced lower smear layer scores compared with the group prepared with the rectangular file.

Conclusion: Root canal preparations using files with different cross-section shapes (e.g., triangular and rectangular), followed by irrigation with $2.5 \%$ $\mathrm{NaOCl}$ and 17\% EDTA, produced smear layers in the apical third area. However, root canal preparations using files with a triangular cross-section shape were shown to reduce smear layer production compared with files with a rectangular cross-section shape.

Keywords: Tooth apex, Rectangular cross-section, Root canal preparation, Smear layer, Triangular cross-section.

(C) 2020 The Authors. Published by Innovare Academic Sciences Pvt Ltd. This is an open access article under the CC BY license (http://creativecommons. org/licenses/by/4. 0/) DOI: http://dx.doi.org/10.22159/ijap.2020.v12s2.0P-21

\section{INTRODUCTION}

Root canal treatment is a procedure to eliminate pulp infection and support periapical tissue healing, comprising three important steps (i.e., the endodontic triad), namely, access, cleaning and shaping, and obturation. Cleaning and shaping involves mechanochemical processes which are essential to achieve successful treatment [1]. However, during cleaning and shaping step, a thin smear layer may be produced when endodontic instruments touch the root canal wall, which consists of organic materials (collagen, odontoblast processes, pulp tissue, blood, and bacteria) and inorganic materials from unextracted dental debris (calcium hydroxyapatite and tricalcium phosphate) [2]. The presence of smear layer may clog dental tubules, providing substrates for bacterial growth and preventing antibacterial agents from entering the tubules. It may also interfere with the obturation step and the overall success of endodontic treatment $[3,4]$. In addition, smear layer may develop in apical third part of root canal, which is difficult to reach, making it a critical zone in the root canal treatment process [5].

Effectiveness of root canal preparation can be assessed by minimal production of a smear layer [6]. Several approaches have been developed to achieve optimal root canal cleanliness, such as utilization of nickel-titanium (Ni-Ti) rotary instruments [7] and chemical irrigation with solutions such as $2.5 \%$ sodium hypochlorite $(\mathrm{NaOCl})$ and $17 \%$ ethylenediaminetetraacetic acid (EDTA) to remove both organic and inorganic debris, respectively [4]. As such, endodontic instruments and chemical irrigation methods for minimal smear layer production are constantly being developed. Unique file configuration used for root canal preparation is also believed to play significant role in smear layer production. For instance, instruments with radial lands tend to condense dental debris to the root canal wall, producing more of a smear layer, while instruments with active cutting edges have better eroding capacities, leaving less of a smear layer in the root canal wall [8].

One recent innovation in the development of endodontic instrument's configuration was a single file for root canal preparation, which its utilization provides several advantages, such as minimizing preparation time, cross-contamination, and risk of broken file in the canal [9]. Additional modifications to the shape of the single file have also been carried out. Accordingly, commercial single files are currently available in both triangular and rectangular shapes, as well as an S-shape. However, studies evaluating smear layer production after root canal preparation, particularly in the apical third, with single files of different cross-section shapes remain limited. Therefore, in the present study, we aimed to compare smear layer production in the apical third of root canal wall between single files with either triangular or rectangular cross-section shape.

\section{MATERIALS AND METHODS}

\section{Materials}

In this study, the experimental design included single-file crosssection shape as the independent variable and smear layer score as the dependent variable. A total of 32 extracted human premolar samples from mandibles were divided equally into two groups. The inclusion criteria included teeth with an average length of $20 \mathrm{~mm}$, single and straight root canals as confirmed by radiologic assessment, a diameter approximately the same as K-file number 15 , apical teeth completely covered, and absence of defects in the root. The teeth in the first group were prepared using a single file with a triangular cross-section shape 
(One Curve ${ }^{\circledR}$ from Micro Mega, Besancon, France; $n=16$ ), whereas those in the second group were prepared using a single file with a rectangular cross-section shape (Hyflex EDM ${ }^{\circledR}$ from Coltene/Whaledent, Altstatten, Switzerland; $\mathrm{n}=16$ ). All samples were soaked in saline solution before root canal preparation.

\section{Preparation of root canal}

The root canals in the teeth were prepared using files from the respective groups based on the manufacturer's instructions. This was performed using a circumferential motion at a rotation rate of $300 \mathrm{rpm}$ (for One Curve ${ }^{\circledR}$ ) and 400 rpm (for Hyflex EDM $^{\circledR}$ ) with a torque of 2.5 $\mathrm{N}-\mathrm{cm}$. After preparation, all tooth samples were manually irrigated using a combination of $2.5 \% \mathrm{NaOCl}$ and $17 \%$ EDTA and were dried using paper point. To access the inner part of the root canal, the teeth were cut vertically using a chisel.

\section{Evaluation of smear layer in root canal}

The smear layer from the inner root canal wall was then observed using a scanning electron microscope (SEM; Inspect F50 ${ }^{\circledR}$ from FEI, The Netherlands) and quantified using a modified scoring system according to Foschi et al. This quantification was performed by two different observers who were blinded to the experimental group. The Kappa reliability test between the observers was conducted before the determination of definitive smear layer score from each sample. The scoring system was as follows: A score of 1 indicated that $>75 \%$ of the apical third wall was free from a smear layer, and the dental tubules were all opened; a score of 2 indicated that about $50 \%-70 \%$ of the apical third wall was free from a smear layer, and the dental tubules were partly opened; and a score of 3 indicated that $<50 \%$ of the apical third wall was free from a smear layer, and the dental tubules were observed but were limited [4].

\section{Experimental data processing}

The data collected were recorded and processed using Statistical Package for the Social Sciences (SPSS) version 23.0. Statistical analyses were conducted using the Chi-squared test with a significance level of 0.05. If the Chi-squared test criteria were not met, the Mann-Whitney U-test was used instead.

\section{Ethical consent}

Regarding ethical approval, this study was exempted from the obligation to obtain approval according to the Dentistry Research Ethical Committee of the University of Indonesia.

\section{RESULTS AND DISCUSSION}

The Kappa test value obtained before the definitive smear layer score determination was $>0.8(\kappa=0.904)$, indicating that the observers agreed in terms of the scoring system. Table 1 presents the smear layer scoring distribution in the apical third of the root canal wall prepared using the single files of different shapes. The representation of the SEM from each score in this experiment is shown in Fig. 1. The group prepared with the triangular file (One Curve ${ }^{\circledR}$ ) had six samples (37.5\%) with a score of 1 , while the group prepared with the rectangular file (Hyflex EDM ${ }^{\circledR}$ ) had only one sample $(6.3 \%)$ with a score of 1 . In addition, a score of 3 was observed in 4 samples (25\%) in the One Curve ${ }^{\circledR}$ group but 9 samples
$(56.3 \%)$ in the Hyflex EDM ${ }^{\circledR}$ group. Therefore, while differences were observed, root canal preparation procedure still left a smear layer in the apical third of the root canal wall, regardless of instruments used for preparation in both groups. However, teeth prepared with the One Curve ${ }^{\circledR}$ file exhibited a reduction in the smear layer compared with those prepared using the Hyflex EDM ${ }^{\circledR}$ file.

The data collected from this experiment did not meet Chi-squared test criteria due to the presence of cells with expected values of less than 5 but that were more than $20 \%$ of the total cells (the allowed limit was one cell, obtained from $20 \% \times$ six cells). In the experimental data, there were two cells (33\%) with expected values of less than 5 [10]. While the smear layer scoring system was considered strict, cell merging was not conducted, and the Mann-Whitney U-test was used to analyze the data. From the Mann-Whitney U-test, $\mathrm{p}=0.026$ was obtained, indicating that there was a statistically significant difference in smear layer quantity in the apical third of the root canal wall between preparation using a file with either a triangular (One Curve ${ }^{\circledR}$ ) or rectangular (Hyflex EDM ${ }^{\circledR}$ ) cross-section shape followed by irrigation with $2.5 \% \mathrm{NaOCl}$ and $17 \%$ EDTA. Further, comparison using Mann-Whitney U-test of the rank of both groups revealed that the group prepared with the triangular file (average rank 13.06) had a reduced smear layer quantity compared with those prepared with the rectangular file (average rank 19.94).

Preparation step in root canal treatment plays a significant role in supporting the overall success of the procedure. However, during the preparation step, a smear layer consisting of both organic and inorganic materials of dental debris can be produced, which can interfere with the endodontic treatment [7]. Therefore, instruments that produce a minimal smear layer are preferable. Endodontic Ni-Ti rotary instruments are continuously developing to achieve a minimal smear layer, as studies have revealed that conventional stainless steel K-files produce more of a smear layer in the apical third of the root canal wall, which is influenced by preparation techniques and file design [7]. Our results from the present study indicated that the shape of the file utilized for root canal preparation influenced smear layer production, with the teeth prepared using a triangular file developing less of a smear layer compared with those prepared using a rectangular file.

The apical third of the root canal wall is considered a critical zone for instrumentation. As such, the cleaning and shaping of this part

Table 1: Smear layer score distribution in tooth samples prepared with files of a triangular (One Curve ${ }^{\circledR}$ ) and rectangular (Hyflex EDM ${ }^{\circledR}$ ) cross-section shape*

\begin{tabular}{|c|c|c|c|c|c|c|c|}
\hline \multirow[t]{3}{*}{ Group } & \multicolumn{6}{|c|}{ Smear layer score } & \multirow[t]{2}{*}{ p-value } \\
\hline & \multicolumn{2}{|l|}{1} & \multicolumn{2}{|l|}{2} & \multicolumn{2}{|l|}{3} & \\
\hline & $\mathbf{n}$ & $\%$ & $\mathbf{n}$ & $\%$ & $\mathbf{n}$ & $\%$ & 0.026 \\
\hline One Curve $^{\circledR}(\mathrm{n}=16)$ & 6 & 37.5 & 6 & 37.5 & 4 & 25 & \\
\hline Hyflex $\operatorname{EDM}^{\circledR}(\mathrm{n}=16)$ & 1 & 6.3 & 6 & 37.5 & 9 & 56.3 & \\
\hline
\end{tabular}

*Mann-Whitney U-test, $\mathrm{p}<0.05$
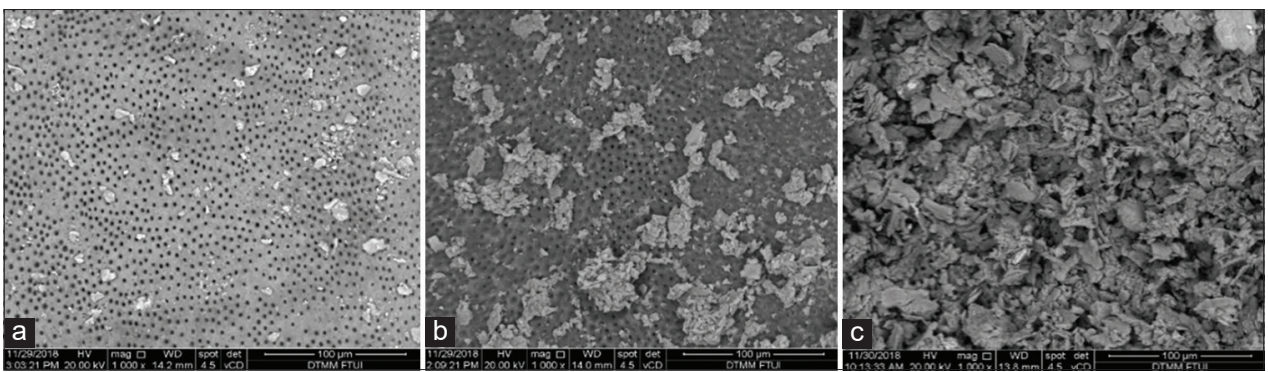

Fig. 1: Scanning electron microscope representation $(\times 1000)$ of tooth samples after preparation with a triangular cross-section shaped file (One Curve ${ }^{\circledR}$ ) with a smear layer score of (a) 1 with clear dental tubules, (b) 2 with partial closure of dental tubules, and (c) 3 with limited dental tubules, according to the modified Foschi scoring system 
of the canal during the endodontic treatment is challenging. Indeed, in this area, there are a lot of ramifications, rendering the removal of dental debris difficult [5]. In addition, a considerable number of microorganisms and the smear layer are found in the apical third, which simultaneously can cause secondary infection and interfere with the success of the treatment $[5,11]$. Some studies have also revealed that root canal cleaning is influenced by the volume of irrigation fluid reaching the area. Moreover, in the apical third area, there is a tendency for air to be trapped, which limits fluid turnover (vapor lock effect) and reduces irrigation efficiency [12-14].

Several factors have been considered to potentially influence the production of the smear layer during root canal preparation, including the configuration and cross-section design of the utilized files. Although significantly different, the smear layer was still observed in samples prepared with both instruments in this study. This may be due to the presence of non-cutting tip on both instruments, which is not aggressive at cutting dentin and hence leaving a smear layer in the apical third of the root canal wall [15].

The present study compared the smear layer quantity using single files with either a triangular or a rectangular cross-section shape. Indeed, the shape of the file is another factor that may influence smear layer production. The triangular cross-section shaped file was represented by the One Curve ${ }^{\circledR}$ file, whereas the rectangular cross-section shaped file was represented by the Hyflex EDM ${ }^{\circledR}$ file. The cross-section shape of both files was not constant along their respective axes. In addition, several features may have influenced the differences observed in smear layer production, including the file contact area with the root canal wall, the flute, and the presence of radial lands. One Curve ${ }^{\circledR}$ file has a triangular cross-section shape with three cutting edges in the distal part, two cutting edges in the middle part, and two cutting edges with an S-shape in the proximal part. This configuration allows for three possible contact areas between the cutting edge of the file and the root canal wall, with a deep and wide flute. The flute refers to the groove on the working surface and functions as a container for dental debris to be further removed from the root canal. The effectiveness of the flute depends on its depth, width, and configuration. Indeed, deeper flutes are more likely to be effective in removing debris and leaving less of a smear layer $[16,17]$

Furthermore, cross-section in the proximal part of the One Curve ${ }^{\circledR}$ file is S-shaped with two cutting edges, allowing for effective root canal preparation and debris elimination toward the corona, with the SEM appearance free from a smear layer and most of the dental tubules opened. This is in accordance with a study reporting that italic S-shaped files (MTwo ${ }^{\circledR}$ and Reciproc ${ }^{\circledR}$ ) have better performance in leaving less of a smear layer during root canal preparation compared with triangularshaped file $\left(\right.$ ProTaper $\left.^{\circledR}\right)$ [18].

On the other hand, the Hyflex EDM ${ }^{\circledR}$ file has a different cross-section configuration along its axis. This file is rectangular at the distal, trapezoid at the middle, and almost triangular at the proximal [19]. The larger rectangular cross-section shape of the Hyflex EDM ${ }^{\circledR}$ file provides more contact area with the root canal wall during preparation and less space for debris accumulation and removal toward the corona. Consequently, the smear layer and debris tend to be trapped between the root canal wall and the instrument.

Apart from their shapes, other features of the One Curve ${ }^{\circledR}$ and Hyflex EDM $^{\circledR}$ files may explain our results in the present study. These two files have different tapers, with the One Curve ${ }^{\circledR}$ file having a constant taper of $6 \%$, whereas the Hyflex $\mathrm{EDM}^{\circledR}$ file has a varying taper along its axis, ranging from $4 \%$ to $8 \%$. Theoretically, the varying taper should minimize contact between the file and root canal wall; thus, debris and smear layer elimination would be expected to be more efficient compared with the constant tapered file [12]. However, our results from the present study revealed that the tooth samples prepared with the varying tapered file (Hyflex EDM ${ }^{\circledR}$ ) left more of a smear layer than the constant tapered file (One Curve ${ }^{\circledR}$ ). Our results suggested that the production of the smear layer during root canal preparation using various instruments is likely influenced by additional features, including rake angle and radial land. Several studies have also reported no significant influence of the taper on smear layer clearance $[14,20]$.

Rake angle may influence instrument cutting efficiency and smear layer production during root canal preparation. Rake angle is made from the cutting edge and cross-section perpendicular to the instrument's axis. A positive rake angle (obtuse angle) is more effective in cutting dentin, while a negative rake angle (acute angle) tends to grind dentin, potentially leaving more of a smear layer $[16,18]$. This is in accordance with a study comparing root canal preparation procedures between $\mathrm{K} 3^{\circledR}$ files with a positive rake angle and ProFile ${ }^{\circledR}$ files with a negative rake angle, with the authors reporting that the $\mathrm{K} 3^{\circledR}$ file left less of a smear layer than the ProFile ${ }^{\circledR}$ file. In the present study, the One Curve ${ }^{\circledR}$ file has a positive rake angle, whereas the Hyflex $\mathrm{EDM}^{\circledR}$ has a negative rake angle, and our results were consistent with those of the previous study.

Several limitations should be considered when interpreting the results of the present study. The Hyflex EDM ${ }^{\circledR}$ file has a radial land on its proximal side, which is the surface between the flutes that projects axially from the mid-axis to the cutting edge. This structure tends to condense cut dental debris into the root canal wall, leaving more of a smear layer during preparation $[8,16]$. In a study of the smear layer in root canals prepared using files with reciprocal movement $\left(\right.$ Reciproc $^{\circledR}$ and WaveOne ${ }^{\circledR}$ ) and continuous rotation (MTwo ${ }^{\circledR}$ and ProTaper ${ }^{\circledR}$ ), it was shown that the WaveOne ${ }^{\circledR}$ file with a radial land significantly produced more of a smear layer in the apical third of the root canal wall [18]. This may explain the results of the present study, which higher smear layer scores were found in samples prepared with the Hyflex EDM ${ }^{\circledR}$ file. In addition, during the cutting process of the samples using a chisel, there is a possibility that debris contaminated the inner part of the root canal, thereby influencing the results.

\section{CONCLUSION}

The present study revealed that root canal preparation procedures using files with different cross-section shapes (i.e., triangular and rectangular) still produced a smear layer in the apical third area. However, root canals prepared with the triangular cross-section shaped file had reduced smear layer production compared with those prepared with the rectangular cross-section shaped file.

\section{ACKNOWLEDGMENT}

This study was supported by the Directorate of Research and Community Engagement of Universitas Indonesia, funded by PITTA 2019 grant funds. In addition, we would like to thank Yus Prasetyo, S.T, M. Eng as the SEM person in charge of the Faculty of Metallurgical Engineering, Universitas Indonesia, for providing equipment and assistance needed for this study.

\section{CONFLICTS OF INTEREST}

The authors declare no conflicts of interest in this study.

\section{REFERENCES}

1. Siquerra JF, Loupes H. Treatment of Endodontic Infection. Berlin: Quintessence Publishing; 2011. p. 236-84.

2. Silveira LF, Silveira CF, Martos J, de Castro LA. Evaluation of the different irrigation regimens with sodium hypochlorite and EDTA in removing the smear layer during root canal preparation. J Microsc Ultrastruct 2013;1:51-6.

3. Violich DR, Chandler NP. The smear layer in endodontics-a review. Int Endod J 2010;43:2-15.

4. Foschi F, Nucci C, Montebugnoli L, Marchionni S, Breschi L, Malagnino VA, et al. SEM evaluation of canal wall dentine following use of $\mathrm{M}$ two and ProTaper NiTi rotary instruments. Int Endod $\mathrm{J}$ 2004;37:832-9.

5. Ricucci D, Siqueira JF Jr. Fate of the tissue in lateral canals and apical 
ramifications in response to pathologic conditions and treatment procedures. J Endod 2010;36:1-15.

6. Hülsmann M, Peters OA, Dummer PM. Mechanical preparation of root canals: Shaping goals, techniques and means. Endod Top 2005;10:30-76.

7. Bertrand MF, Pizzardini P, Muller M, Médioni E, Rocca JP. The removal of the smear layer using the quantec system: A study using the scanning electron microscope. Int Endod J 1999;32:217-24

8. Jeon I, Spångberg LS, Yoon T, Kazemi RB, Kum K. Smear layer production by 3 rotary reamers with different cutting blade designs in straight root canals: A scanning electron microscopic study. Oral Surg Oral Med Oral Pathol Oral Radiol Endodontol 2003;96:601-7.

9. Sharma P, Goel M, Verma S, Sachdeva GS, Sharma N, Kumar V. Entering a new era in endodontics with revolutionary single file systems: A comprehensive review. EC Dent Sci 2016;3:1100-22.

10. Gaur AS, Gaur SS. Statistical Methods for Practice and Research: A Guide to Data Analysis Using SPSS. $2^{\text {nd }}$ ed. New Delhi: SAGE Publication; 2009. p. 91-8

11. Young GR, Parashos P, Messer HH. The principles of techniques for cleaning root canals. Aust Dent J Suppl 2007;52:52-63.

12. Pirani C, Buonavoglia A, Cirulli PP, Baroni C, Chersoni S. The effect of the NRT files instrumentation on the quality of the surface of the root canal wall. J Appl Biomater Funct 2012;10:136-40.
13. Tay FR, Gu L, Schoeffel GJ, Wimmer C, Susin L, Zhang K, et al. Effect of vapor lock on root canal debridement by using a side-vented needle for positive-pressure irrigant delivery. J Endod 2010;36:745-50.

14. Plotino G, Özyürek T, Grande NM, Gündoğar M. Influence of size and taper of basic root canal preparation on root canal cleanliness: A scanning electron microscopy study. Int Endod J 2019;52:343-51.

15. Sanghvi Z, Mistry K. Design features of rotary instruments in endodontics. J Ahmedabad Dent Coll Hosp 2011;2:6-11

16. Metzger Z, Basrani B, Goodis HE. Instruments, materials, and devices. In: Hargreaves KM, Cohen S, editors. Cohen's Pathways of the Pulp. New York: Elsevier; 2011. p. 223-80.

17. Jahromi MZ, Fathi MH, Zamiran S. Experimental study of smear layer and debris remaining following the use of four root canal preparation systems using scanning. J Islam Dent Assoc Iran 2013;25:179-85.

18. Bürklein S, Hinschitza K, Dammaschke T, Schäfer E. Shaping ability and cleaning effectiveness of two single-file systems in severely curved root canals of extracted teeth: Reciproc and WaveOne versus Mtwo and ProTaper. Int Endod J 2012;45:449-61.

19. Singh H, Kapoor P. Hyflex CM and EDM files: Revolutionizing the art and science of endodontics. J Dent Heal Oral Disord Ther 2016;5:5-8.

20. Arvaniti IS, Khabbaz MG. Influence of root canal taper on its cleanliness: A scanning electron microscopic study. J Endod 2011;37:871-4 